\title{
Adaptive control of drilling by identifying parameters of object model under nonstationarity conditions
}

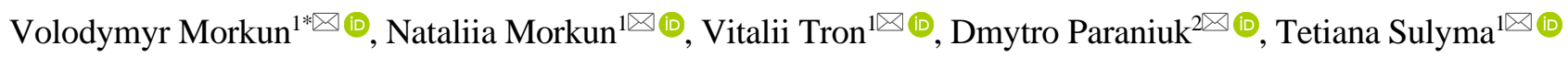 \\ ${ }^{1}$ Kryvyi Rih National University, Kryvyi Rih, 50027, Ukraine \\ ${ }^{2}$ PJSC “ArcelorMittal Kryvyi Rih", Kryvyi Rih, 50095, Ukraine \\ *Corresponding author: e-mailmorkunv@gmail.com, tel. +380679762925
}

\begin{abstract}
Purpose. The research is intended to investigate and synthesize adaptive control over drilling by identifying parameters of an object model under non-stationarity conditions.
\end{abstract}

Methods. Under conditions of rapidly changing borehole drilling indices, a two-level adaptive control strategy is applied, combining investigation of drilling and its control. The structure of the control system includes an additional block of forming the model on the basis of data on indirect features.

Findings. The research develops a method for seeking the extremum developed for the object whose dynamics is described by a first-order linear differential equation. The method allows to determine the value of the output signal by evaluating the initial phase of the transient process caused by the changed input signal for a set step.

Originality. The suggested algorithm of noise-free identification makes it possible to assess the factor of the control object transfer under the action of random disturbances. The data obtained is used to adjust the gain factor of the controller in the closed loop automatic control system of drilling.

Practical implications. The suggested structure and algorithm of drilling control allow enhancing drilling efficiency by ensuring relevant mechanical drilling rates through defining corresponding rotation speeds and axial loads of a drilling tool.

Keywords: adaptive control, drilling, non-stationarity, identification, model

\section{Introduction}

Development and introduction of multilevel automatic control systems of maximum economic efficiency at mining and concentration enterprises are applicable only if a system-based approach is used to solve automation tasks when a process, equipment, raw materials and automation means are considered simultaneously. Even when general regularities of a process are known, knowledge of raw material properties and equipment conditions as well as application of improved means of complex automation are necessary prerequisites of efficiency [1]-[2].

The control system functioning, choice of control parameters and laws are based on a mathematical model involving all known regularities of a process. The constant (unchanged) model cannot result in an efficient control system for nonstationary processes, as actual characteristics of an object change. Thus, changeable, unfixed models can appear more efficient for the control system. Adaptive systems meet the mentioned requirements as they are noted for adjustable characteristics resulting in improved indices of the system functioning. This fact allows using adaptive systems when a priori data on external conditions of the system functioning is incomplete, produce the same adaptive systems for working in a variety of conditions and applying them to changing external conditions.

\section{Literature review}

Automatic control of processes at various stages of iron ore mining and processing can be enhanced by applying the data on a process while controlling it [3]-[8]. The data on the process progress can be obtained both by direct measurements and applying a mathematical model [9]-[16].

Considering that drilling characteristics are of random non-stationary character, it is reasonable to use methods of adaptive control with the object model identifier while synthesizing this process control [17]-[20]. Generally speaking, in forming adaptive control of rock drilling, one should consider the following types of input actions of the control object - defining $X^{*}(t)$, controlling $U(t)$ and disturbing $Z(t)$. The object behaviour characterized by output variables $Y(t)$ depends on a variety of unknown parameters $\xi$ with an established set of admissible values $\Xi$, among which physical and mechanical properties of various rocks should be highlighted. In this particular case, there is a need to form the control type that ensures the given indices of drilling quality under all admissible values of unknown parameters $\xi$.

Current investigations indicate that drilling can be improved on the basis of complex analysis of characteristics of drilling machines and environmental factors, the geological 
structure of a deposit being essential. Consequently, formation and maintenance of optimal mode parameters under continuous changes of disturbing actions determine the necessity of applying some specific methods of control [21]-[25].

Expedient application of adaptive automatic drilling systems implying extremal control as its simplest is grounded in [22], [23]. It is specified that increased axial load and rotation of a drilling tool to a certain limit cause the increased mechanical drilling rate. There are optimal dependencies of rotation $n$ and axial load $G_{a x}$. The controlled axial load and drilling tool rotation which are proportional and correspondingly inversely proportional to rock hardness $f$ should be considered optimal.

Considering the dependencies, a block scheme of the automatic search system for optimal parameters of a drilling mode is built [22], [23]. In this control system, a signal of the sensor SV of the drilling rate $U_{O C 1}$ is transmitted to the input of the extremal controller EC. Its operational scheme controls the axial load by influencing the input of the hydraulic drive HD. The signal $U_{O C 1}$ is given to the input of the functional transducer FT affecting the controlled drive CD, which, according to the efficient ratio of $n$ and $G_{a x}$, changes the drilling tool rotation. The extremal controller based on the difference of the instant value of mechanical speed and the maximum value fixed by the extremal controller $\Delta V_{\text {mech }}=V_{\text {ins }}-V_{\text {max }}$ provides a command for the operational scheme to decrease the axial load. Thus, considering optimum drilling conditions for particular rock hardness, the maximum drilling rate is defined.

On the assumption of a wide range of characteristics of iron ore materials produced by national mining enterprises, the geological structure of drilled rocks should be taken into account. Conducted researches of correlation between drilling data and geological information [25] reveal a high correlation rate between drilling parameters and data of geophysical exploration. The following parameters are studied: drilling rate, rotation, axial load and torque. Borehole data were used to define rock types in boreholes and the correlation of parameters of the geological structure model based on drilling characteristics analysis and parameters of the geological structure in proximity to drilling sites. The data on the closest borehole were compared to data of drilling monitoring. The research results indicate a high correlation rate between drilling parameters (drilling rate and torque) and the rock type.

Investigations [1] reveal that the drilling rate decreases in hard rocks and increases in softer ones. It should be noted that analyzed torque dynamics also allows distinguishing hard and soft rocks, yet it contradicts the drilling rate dynamics. On the assumption that to achieve the best drilling rate, there is some optimal value of axial load, the latter should be controlled to increase drilling efficiency. As a result, dynamics of this parameter is unable to reflect characteristics of drilled rock types. In other words, application of axial load as the only indicator of rock properties is not expedient.

The research is intended to investigate and synthesize adaptive control over drilling by identifying an object's parameters under non-stationary conditions.

\section{Materials and methods}

Under conditions of rapidly changing indices of borehole drilling, a two-level adaptive control strategy combining investigation of drilling and its control should be used [17], [26].
When applied to exploration boreholes with various rock types, the structure of the control system should include an additional block of forming a model (Fig. 1).

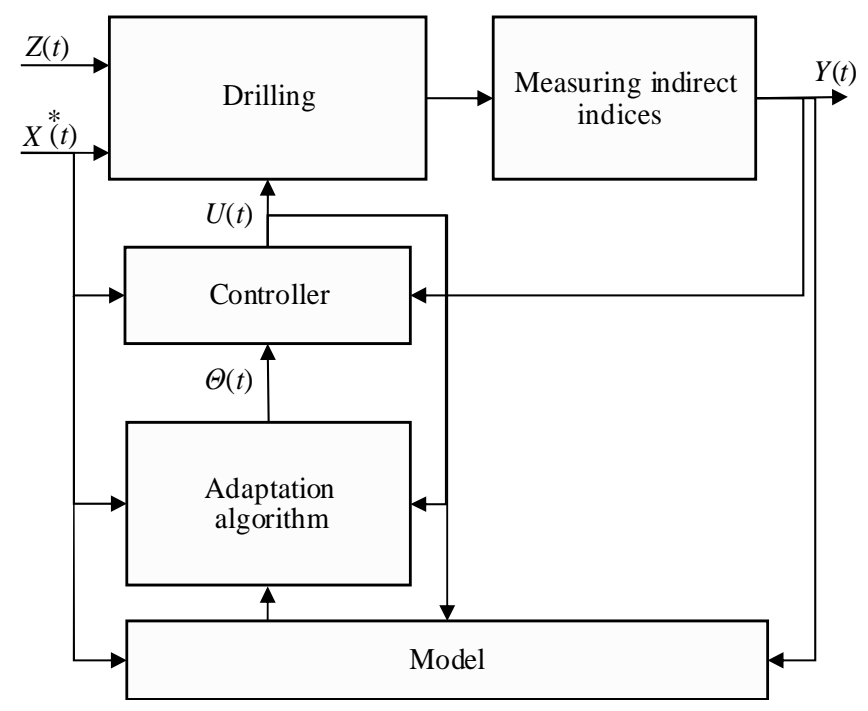

Figure 1. Adaptive control system of drilling

The data on the process progress can be received from direct measurements and by interpreting indirect indicators [25]-[27]. The parameters of drilling rate, rotation, traction and torque are studied. In [1], except for the mentioned parameters, axial load application is studied to identify the geological structure of drilled rocks.

Let us consider the problem of controlling the object the behaviour of which is described by the following differential equation:

$\sum_{t=1}^{n} a_{i} x^{(t)}+a_{0} x^{(t)}=k_{0} u(t)$

where:

$x(t)$ - a controlled coordinate;

$x^{j}(0)=0(j<n)$;

$a_{1}-$ a dynamic factors of the object;

$k_{0}-$ an unknown static factor of the object;

$u(t)$ - a controlling action.

The following conditions are supposed to be observed: $k_{\min } \leq k_{0} \leq k_{\max } ; \quad a_{1}=\mathrm{const} ; \quad u(t)=k_{p}\left[k_{n} \varepsilon(t)+\int_{0}^{t} \varepsilon(\tau) d \tau\right]$ $\varepsilon(t)=q(t)-x(t)$, ensuring high-quality processing of the step action $q(t)$; only the controlled coordinate $x(i)$ and its assessed derivative $\dot{y}(t)$ can be observed:

$\tau \dot{y}+y=x, y(0)=0$.

One should find the equation ensuring the processed step action close to the optimal one in terms of the maximum stability rate irrespective of $k_{0}$.

The required control $u(t)$ will be searched for in the form of:

$u(t)=k_{p}(t)\left[k_{u} \varepsilon(t)+k_{u} \int_{0}^{t} \varepsilon(t) d \tau\right]$

$\varepsilon(t)=g(t)-y(t)$, 
where:

$k_{p}(t)-$ a piecewise constant function.

The problem involves choosing the piecewise constant function $k_{p}(t)$ resulting from identification. The condition $|\varepsilon(e)|>\varepsilon_{l z}$ is necessary for identification, i.e. the control error is beyond some critical level.

Identification of $k_{0}$ is based on the following. Let a stepwise disturbance of the amplitude $q_{0}$ be delivered to system (1) at the moment $t=0$ :

$q(t)=\left\{\begin{array}{lr}0 & t<0 \\ q_{0} & \leq 0\end{array}\right.$

Substituting (4) into the initial system (1)-(3) and passing to coordinates $\left(y, \dot{y}, \ldots, y^{n-2}\right)$, we apply the equivalent system:

$\sum_{i=1}^{n+1} d_{i} y^{(i+1)}(t)+d_{0} \dot{y}(t)+k k_{n} \dot{y}(t)+k k_{n} y(t)=k k_{0} q(t) ;$

$y^{(t)}(0) i=0,1, \ldots n$

$y^{n+1}(0)=k k_{n} d_{n+1 q_{0}}^{-1}$.

Let us present $y(t)$ by the series:

$y(t)=\sum_{t=0}^{\infty} y_{i}\left(\frac{t^{i}}{t !}\right)$

We differentiate $(6)$ by $(n+2)$ times and substitute it into (5). Equating the factors of the same power $t$, we obtain the equations for determining any factor $y_{i}$ applying $m$ terms of the series:

$y_{m}(\Delta t)=q_{0}\left(A_{1} k+A_{2} k^{2}+, \ldots, A_{l} k^{l}\right)$,

where:

$A_{i}=\sum_{j=i(n+1)}^{m} a_{j, i} \frac{(\Delta t)}{j l}, l=\left[\frac{m}{n+1}\right]$.

The factors $A_{i}$ are rapidly decreasing in absolute magnitude, while $i$ is increasing. Therefore, we can consider $y_{m}(\Delta t)$ a polynomial in smaller degrees of $k$ and linearly dependent on $k$ under smaller $\Delta t$. Thus, if $y_{m}^{o p t}(\Delta t)$ is known for some optimal transient process, its value can indicate what fold $k_{0}$ has changed.

On this basis, the algorithm is synthesized. The moment, when all derivatives till $n$-1 are equal to zero, is considered initial. At the moment $\Delta$, the value $y$ is measured and the new value of $k$ is considered equal to:

$k_{p}^{H}=k_{p}^{c} M \frac{\varepsilon_{0}}{y_{0}-y(\Delta t)}$,

where:

$\varepsilon_{0}$ - the value of $\varepsilon$ at the initial moment;

$M-$ the proportionality factor considering $k_{p}^{H}=k_{p}^{c}$ for the optimal transient process or $A=\frac{\varepsilon_{0}}{y_{0}-y(\Delta t)}=1$.

\section{Results}

To realize this algorithm, it is necessary to find out for which the values of $\Delta t$, the correction based on the linear model is left admissible for the general case as well. We study the case when the feedback system is of the third order because for fixed $\Delta t$ and $m$ the increased $n$ causes decreased contribution of non-linear terms as compared to that of the linear term, i.e. the impact of highest degree terms according to $k$ in $y_{m}(\Delta t)$ reduces. As the system is synthesized on the basis of the criterion of the maximum stability rate which ensures high stability of the system along with its quality, for proportional-integral actions such systems have three n-fold roots [28]-[31], the system looks like:

$k k_{u} y+\left(a_{2}+k k_{n}\right) y+3 y+y=k k_{u}$

$y_{0}=0 ; y_{1}=0 ; y_{2}=k k_{u}$.

Solving for $a_{1}=0$, we obtain $k=1, k_{n}=3, y_{3}=1$.

For $m=7$ we obtain the following decomposition:

$y_{7}(\Delta t)=A_{1} k+A^{2} k^{2}+A_{3} k^{3}$.

As it is almost impossible to determine the moment when all derivatives are equal to zero, the initial moment of the algorithm is set by $\dot{y}=0$. Besides, as $\dot{y}(t)$ is known, instead of (10), we use the correction $y_{0}-y(\Delta t) \approx k_{p}^{0} M\left(\frac{\varepsilon}{\dot{y}(\Delta t)}\right)$.

To reduce the impact of random disturbances at the moment $\Delta t$, it is reasonable to use evaluation of $\max \dot{y}(t) 0 \leq t \leq \Delta t$ instead of $\dot{y}(t)$. The gain factor is evaluated by the following formula, when there are no noises in the threshold error [28]:

$k_{p}^{H}=k_{p}^{c} M \frac{\varepsilon(\Delta t)}{\substack{\max \|\dot{\varepsilon}(t)\| \\(0, \Delta t)}}$

where:

$\varepsilon(t)$ - the threshold error.

If there appears a high-frequency noise which is a stationary normal random process, the ratio $\sigma_{\varepsilon} \leq \sigma_{\dot{\varepsilon}}$ is observed where $\sigma_{\varepsilon}^{2}$ is dispersion of $\varepsilon(t)$ and $\sigma_{\dot{\varepsilon}}^{2}$ is dispersion of $\dot{\varepsilon}(t)$. To reduce the dependency of the gain factor because of noises, (11) should be transformed. The linear character of the control system, the following ratio is true:

$\max |\dot{\varepsilon}(t)|=\max _{(0, \Delta t) \text { u.c. }} \dot{\varepsilon}(t)+\max _{(0, \Delta t)} \dot{\varepsilon}_{m}(t)$,

where:

$\dot{\varepsilon}_{\text {u.c. }}(t)$ - a derivative of the useful component of the threshold error;

$\dot{\varepsilon}_{m}(t)-$ a component of the threshold error derivative $\dot{\varepsilon}(t)$ conditioned by the action of the noise.

For this reason, the expression for $k$ should be supplemented by a term, which would compensate the value $\max _{0, \Delta t}\left|\varepsilon_{m}(t)\right|$ and significantly decrease the impact of the noise on the gain factor $k$. 
Let us evaluate the value $\max _{0, \Delta t}\left|\varepsilon_{m}(t)\right|$. Following from [32], if sample functions of the process $\varepsilon_{m}(t)$ are continually differentiated, the following ratio is true:

$\lim P\left\{\max _{0, \Delta t}\left|\max \dot{\varepsilon}_{m}(t)\right|-\sigma_{m} \sqrt{2 \ln \Delta t} \mid<\frac{\ln \ln \Delta t}{\sqrt{\ln \Delta t}}\right\}$.

As it follows from (13), under unlimited long observation of $\Delta t, \max \left|\varepsilon_{m}(t)\right|$ equal to $\sigma_{m} \sqrt{2 \ln \Delta t}$ can be evaluated arbitrary closely.

Duration of $\Delta t$ measurement is determined by frequency properties of the useful component $\dot{\varepsilon}_{\text {u.c. }}(t): \Delta t \approx \omega_{\text {u.c. }}^{-1}$, where $\omega_{\text {u.c. }}$ is a coordinate of the gravity centre of the spectral density of the useful signal:

$$
\omega_{\text {u.c. }}=\frac{0.5 \pi^{-1} \int_{0}^{\infty} \omega S_{m}(\omega) d \omega}{0.5 \pi^{-1} \int_{0}^{\infty} S_{m}(\omega) d \omega} .
$$

If the useful component $\dot{\varepsilon}_{\text {u.c. }}(t)$ and noises $\dot{\varepsilon}_{m}(t)$ are dispersed in the frequency domain, i.e. $\omega_{n n}<<\omega_{n . m}$ is the lower frequency of the component $\dot{\varepsilon}_{\text {u.c. }}(t), \Delta t$ is great as compared to characteristic times $\dot{\varepsilon}_{m}(t)$ and $\max \left|\dot{\varepsilon}_{m}(t)\right|=\sigma_{m} \sqrt{2 \ln \Delta t}$ is observed adequately [28].

To avoid ambiguity of $0 / 0$, it is suggested to determine the gain factor by:

$$
k_{p}^{H}=k_{p}^{c} \frac{\varepsilon k_{2}+\Delta k_{1}}{\max _{(0, \Delta t)}\left|\dot{\varepsilon}_{m}(t)\right|} .
$$

In this case, within the change range of $0<\left|\dot{\varepsilon}_{\text {u.c. } 2}(t)<\infty\right|$ the factor $k \approx 1$.

\section{Discussion}

We are going to consider a one-parameter extremal object: $x=J(\beta, \alpha)$.

To simplify it, let us suppose that the function $J$ depends on just one indefinite constant parameter $\alpha$. If the parameter $\alpha$ were known (for example, determined experimentally before the system is launched), one would have to solve the following equation to find the controlling parameter $\beta$ :

$$
\frac{\partial J}{\partial \beta}=0
$$

with regard to the variable $\beta$.

In this case, the extremal control algorithm includes three operations:

1) identification of the parameter $\alpha$;

2) solving equation (16) and determining the controlling parameter;

3) applying the controlling parameter (action) to the object.

Let the extremal object be described by the equation:

$$
x=(\kappa \beta-\alpha)^{2} .
$$

Applying the experimental action $\beta=\beta^{u}$ (where $\beta^{u}$ ) is a known number) to the object and measuring the output $x=x^{u}$, we obtain the value of the unknown parameter:

$\alpha=\kappa \beta^{u}-\sqrt{x^{u}}=\alpha^{u}$.

Next, solving the equation:

$$
\frac{\partial\left(\kappa \beta-\alpha^{u}\right)^{2}}{\partial \beta}=2\left(\kappa \beta-\alpha^{u}\right) \kappa=0
$$

we find the value of the controlling parameter:

$\beta^{*}=\frac{1}{\kappa} \alpha^{u}$

The two latter operations of the extremal control algorithm can be combined if we use the gradient method and determine:

$\dot{\beta}=-a_{1} \frac{\partial J}{\partial \beta} ; \beta\left(t_{0}\right)=\beta_{0}$,

where:

$a_{1}-$ a positive number.

Applying the value of the parameter $\beta=\beta_{0}$ to object (15) at the moment $t_{0}$ and at the subsequent moment - the values of $\beta(t)$, which are solutions of equation (20), we obtain the time called adaptation time $t_{a d}$ :

$\dot{\beta}=-a_{1} \frac{\partial J}{\partial \beta} ;\left|\beta\left(t_{a d}\right)-\beta^{*}\right| \leq \varepsilon$,

where:

$\varepsilon-$ a quite small positive number;

$\beta^{*}$ - the solution of equation (16).

Thus, before combining the two operations, the object is put under the action of $\beta_{0}$ until equation (16) is solved. After that, the output of the object $k$ is approaching the extremal value $x^{*}$ while solving equation (16) on the basis of the gradient method expressed by equation (20).

Let equation (20) of the adaptation algorithm for object (17) look like:

$\dot{\beta}=-2 a_{1}\left(\kappa \beta-\alpha^{(u)}\right) ; \beta\left(t_{0}\right)=\beta_{0}$.

This equation is solved as follows:

$$
\begin{aligned}
& \beta(t)=\beta_{0} \exp \left[-2 \kappa a_{1}\left(t-t_{0}\right)\right]+ \\
& +\int_{t_{0}}^{t} 2 a_{1} \alpha^{u} \exp \left[-2 \kappa a_{1}\left(t-t_{0}\right)\right] d \tau= \\
& =\beta_{0} \exp \left[-2 \kappa a_{1}\left(t-t_{0}\right)\right]+ \\
& +\left(2 a_{1} \alpha^{u}\right) \exp \left[-2 \kappa a_{1}(t)\right]\left[\left.\frac{1}{2 \kappa a_{1}} e^{10 a_{1} \tau}\right|_{t_{0}} ^{t}\right] .
\end{aligned}
$$

It is easy to notice that if $a_{1}>0$, we have:

$\lim _{t \rightarrow \infty} \beta(t)=\frac{1}{\kappa} \alpha^{u}$,

which coincides with (19). 
Transient processes in the automatic control system can be used as a source of data to identify their characteristics [33][35] and as solution in stability and control problem [36]-[38].

Using the initial phase of the object transient process caused by the changed input signal for the step $\Delta x$, let us consider the method of determining the established value $z(\infty)$ of the object output $z$, i.e. the value of the object output signal determined by the static characteristic $y=f(x)$. If the value $z(\infty)$ is applied to the signum-relay of the step system, the system will perform a search according to the static characteristic of the object. The value $z(\infty)$ can be calculated in a very short time, so the delay of $\Delta t$ between the steps of the performing mechanism can be small and reduced during the extremum seeking [39]-[44].

Let us consider the extremum seeking method applied to the object the dynamics of which is described by the firstorder linear differential equation. Let us assume that the time constant $T_{1}$ of the object is known and remains unchanged under changed conditions of the object. Before the extremal controller is switched on, the condition of the object is characterized by the point $M_{1}$ on the statistic characteristic. If the object were inertia-free, after changing the input signal on $\Delta x$, the output signal value would be immediately equal to $y_{1}=f\left(x_{1}\right)$ according to the static characteristic $y=f(x)$. Yet, because of inertia after changing the input signal on $\Delta x$, the transient process occurs. The increase of the output signal $z_{1}$ of the object at the first step is:

$z_{1}=z-z_{0}=\left[f\left(x_{1}\right)-f\left(x_{0}\right)\right]\left(1-e^{-\frac{t}{T_{1}}}\right)$.

As is seen from (24), under $t \rightarrow \infty$ the value is:

$z_{1} \rightarrow\left[f\left(x_{1}\right)-f\left(x_{0}\right)\right]=d_{i}$.

To determine the value of $d_{1}$ for a short time period, it is necessary to measure the increase of the object output signal $\Delta z_{1 \tau}$ in a given time $\tau$. Applying equation (24) for the moment $\tau$, the value of $d_{1}$ can be determined, because:

$\Delta z_{1 \tau}=d_{1}\left(1-e^{-\frac{\tau}{T_{1}}}\right)$

i.e.:

$d_{1}=\Delta z_{1 \tau} D$

where:

$$
D=\frac{1}{\left(1-e^{-\frac{\tau}{T_{1}}}\right)}
$$

Let us reject the first operation (identification of the parameter $\alpha$ ) of the considered extremal control algorithm. The first part of (16) contains the indefinite parameter $\alpha$. Because of this, let us write the expression of the derivative approximately:

$$
\frac{\partial J}{\partial \beta} \approx \frac{J(\beta+\Delta \beta, \alpha)-J(\beta-\Delta \beta, \alpha)}{2 \Delta \beta},
$$

where:
$\Delta \beta-$ a sufficiently small number called the value of the test step.

Under $\Delta \beta \rightarrow 0$, the expression of the right part of (27) coincides with the derivative $J$.

The values of $J(\beta+\Delta \beta, \alpha), J(\beta-\Delta \beta, \alpha)$ are subjected to direct measurements and the approximate value of the derivative $J$ can be obtained by subtracting the measurement results under the two values of the controlling parameters (spaced $2 \Delta \beta$ apart) and dividing the difference by the value of $2 \Delta \beta$ [45]-[48]. As testing the objects by testing steps of the controlling action requires certain time $T$, a discrete adaptation algorithm in the form of (16) is applied, which is called a discrete algorithm of extremum seeking:

$$
\begin{aligned}
& \beta[(k+1) T]=\beta(k T)- \\
& -\frac{a_{k}}{2 \Delta \beta[J(\beta(k T)+\Delta \beta, \alpha)-J(\beta(k T)-\Delta \beta, \alpha)]}, \\
& k=0,1,2, \ldots
\end{aligned}
$$

\section{Conclusions}

When drilling indices change quite rapidly, it is expedient to use a two-level adaptive control strategy which implies simultaneous investigation and control of the drilling process. Meanwhile, the control system should include model formation based on the data on indirect features.

The method of extremum seeking developed for the object the dynamics of which is described by a first-order linear differential equation allows defining the value of the output signal by the initial phase of the transient process caused by the changed input signal for a set step.

The suggested algorithm of noise-free identification makes it possible to assess the transfer factor of the control object under the action of random disturbances. The data obtained is used to adjust the gain factor of the controller in the feedback automatic control system of drilling.

The suggested structure and algorithm of drilling control allow enhancing drilling efficiency by ensuring relevant mechanical drilling rates through defining corresponding rotation speeds and axial loads of a drilling tool.

\section{Acknowledgements}

The authors express their sincere gratitude to Kryvyi Rih National University for support in conducting research.

\section{References}

[1] Maldynova, A., Osmanov, Z., \& Galiyev, D. (2018). Formation of marketing strategy for promoting an innovative product. Journal of Applied Economic Sciences, 13(7), 1951-1958.

[2] Mustafin, S.A., Duisen, G.M., Zeinullin, A.A., Korobova, E.V. (2019). Evaluation of the choice of borrower rating groups. News of the National Academy of Sciences of the Republic of Kazakhstan, Series of Geology and Technical Sciences, 6(438). https://doi.org/10.32014/2019.2518$170 \mathrm{X} .166$

[3] Segui, J.B., \& Higgins, M. (2002). Blast design using measurement while drilling parameters. Fragblast, 6(3-4), 287-299. https://doi.org/10.1076/frag.6.3.287.14052

[4] Morkun, V., \& Morkun, N. (2018). Estimation of the crushed ore particles density in the pulp flow based on the dynamic effects of highenergy ultrasound. Archives of Acoustics, 43(1), 61-67.

[5] Golik, V., Komashchenko, V., Morkun, V., \& Burdzieva, O. (2017). Experience of metal deposits combined development for South African enterprises. Mining of Mineral Deposits, 11(2), 68-78. https://doi.org/10.15407/mining11.02.068 
[6] Rakishev, B. R., \& Galiev, D. A. (2015). Optimization of the ore flow quality characteristics in the quarry in road-rail transport. Metallurgical and Mining Industry, 7(4), 356-362.

[7] Morkun, V.S., Morkun, N.V., \& Tron, V.V. (2017). Automatic control of the ore suspension solid phase parameters using high-energy ultrasound. Radio Electronics, Computer Science, Control, O(3), 175-182. https://doi.org/10.15588/1607-3274-2017-3-19

[8] Stupnik, M.I., Kalinichenko, V.O., Pysmennyi, S.V., \& Kalinichenko, O.V. (2018). Determining the qualitative composition of the equivalent material for simulation of Kryvyi Rih iron ore basin rocks Naukovyi Visnyk Natsionalnoho Hirnychoho Universytetu, (4), 21-27. https://doi.org/10.29202/nvngu/2018-4/4

[9] Schunnesson, H. (1998). Rock characterisation using percussive drilling. International Journal of Rock Mechanics and Mining Sciences, 35(6), 711-725. https://doi.org/10.1016/s0148-9062(97)00332-x

[10] Abisheva, Z.S., Bochevskaya, E.G., Zagorodnyaya, A.N., Shabanova, T.A., \& Karshigina, Z.B. (2013). Technology of phosphorus slag processing for preparation of precipitated silica. Theoretical Foundations of Chemical Engineering, 47(4), 428-434. https://doi.org/10.1134/s0040579513040027

[11] Golik, V., Hasheva, Z., \& Galachieva, S. (2015). Diversification of the economic foundations of depressive mining region. The Social Sciences (Pakistan), 10(6), 746-749.

[12] Fedko, M., Kolosov, V., Pismennyi, S., \& Kalinichenko, Ye. (2014) Economic aspects of change-over to TNT-free explosives for the purposes of ore underground mining in Kryvyi Rih basin. Naukovyi Visnyk Natsionalnoho Hirnychoho Universytetu, (4), 79-84.

[13] Abisheva, Z.S., Blaida, I.A., Ponomareva, E.I., \& Rozen, A.M. (1995). Effect of amine structure on gallium extraction from hydrochloric acid solutions. Hydrometallurgy, 37(3), 393-399. https://doi.org/10.1016/0304-386x(94)00016-v

[14] Golik, V., Razorenov, Y., \& Polukhin, O. (2015). Metal extraction from ore benefication codas by means of lixiviation in a disintegrator. International Journal of Applied Engineering Research, 10(17), 38105-38109.

[15] Stupnik, N., Fedko, M., Pismenniy, S., \& Kolosov, V. (2014). Development of recommendations for choosing excavation support types and junctions for uranium mines of state-owned enterprise SkhidHZK. Naukovyi Visnyk Natsionalnoho Hirnychoho Universytetu, (5), 21-25.

[16] Golik, V.I., Rasorenov, Y.I., \& Efremenkov, A.B. (2014). Recycling of metal ore mill tailings. Applied Mechanics and Materials, (682), 363-368. https://doi.org/10.4028/www.scientific.net/amm.682.363

[17] Yegupov, N. (2001). Metody robastnogo, neyro-nechetkogo i adaptivnogo upravleniya. Moskva, Rossiya: MGTU im. N.E. Baumana.

[18] Tkachov, V., Bublikov, A., \& Isakova, M. (2013). Control automation of shearers in terms of auger gumming criterion. Energy Efficiency Improvement of Geotechnical Systems, 137-144. https://doi.org/10.1201/b16355-19

[19] Sudakov, A., Dreus, A., Sudakova, D., \& Khamininch, O. (2018). The study of melting process of the new plugging material at thermomechanical isolation technology of permeable horizons of mine opening. E3S Web of Conferences, (60), 00027. https://doi.org/10.1051/e3sconf/20186000027

[20] Tkachov, V., Bublikov, A., \& Gruhler, G. (2015). Automated stabilization of loading capacity of coal shearer screw with controlled cutting drive. New Developments in Mining Engineering 2015: Theoretical and Practical Solutions of Mineral Resources Mining, 465-477. https://doi.org/10.1201/b19901-82

[21] Khramenkov, V. (2011). Avtomatizatsiya proizvodstvennykh protsessov. Tomsk, Rossiya: Tomskiy politekhnicheskiy universitet.

[22] Kozlovskiy, Ye. (1975). Optimizatsiya protsessa razvedochnogo bureniya. Moskva, Rossiya: Nedra.

[23] Kumar, R., Kumaraswamidhas, L.A., Murthy, V.M.S., \& Vettivel, S (2019). Experimental investigations on machine vibration in blast-hole drills and optimization of operating parameters. Measurement, (145), 803-819. https://doi.org/10.1016/j.measurement.2019.05.069

[24] Pysmennyi, S., Brovko, D., Shwager, N., Kasatkina, I., Paraniuk, D., \& Serdiuk, O. (2018). Development of complex-structure ore deposits by means of chamber systems under conditions of the Kryvyi Rih iron ore field. Eastern-European Journal of Enterprise Technologies, 5(1(95)), 33-45. https://doi.org/10.15587/1729-4061.2018.142483

[25] Scoble, M.J., Peck, J., \& Hendricks, C. (1989). Correlation between rotary drill performance parameters and borehole geophysical logging. Mining Science and Technology, 8(3), 301-312. https://doi.org/10.1016/s0167-9031(89)90448-9

[26] Morkun, V., Tron, V., \& Paranyuk, D. (2017). Neuro-fuzzy identification of drilling control system adapted to rock types. 2017 IEEE Inter- national Young Scientists Forum on Applied Physics and Engineering (YSF), 12-15. https://doi.org/10.1109/ysf.2017.8126584

[27] Morkun, V., Morkun, N., \& Pikilnyak, A. (2015). The study of volume ultrasonic waves propagation in the gas-containing iron ore pulp. $\mathrm{Ul}$ trasonics, (56), 340-343. https://doi.org/10.1016/j.ultras.2014.08.022

[28] Shubladze, A., Gulyayev, S., Tsaguriya, H., Morkun, V., \& Khorol'skiy, V. (1981). Zashchishchennyy algoritm identifikatsii dlya adaptivnykh sistem upravleniya tekhnologicheskimi protsessami. Izvestiya VUZov. Gornyy Zhurnal, (2), 121-129.

[29] Daneshvar, M., Mohammadi-Ivatloo, B., \& Zare, K. (2020). Two-stage optimal robust scheduling of hybrid energy system considering the demand response programs. Journal of Cleaner Production, (248), 119267. https://doi.org/10.1016/j.jclepro.2019.119267

[30] Yue, Z.Q., Lee, C.F., Law, K.T., \& Tham, L.G. (2004). Automatic monitoring of rotary-percussive drilling for ground characterization illustrated by a case example in Hong Kong. International Journal of Rock Mechanics and Mining Sciences, 41(4), 573-612. https://doi.org/10.1016/j.ijrmms.2003.12.151

[31] Schunnesson, H., \& Holme, K. (2015). Drill monitoring for geological mine planning in the Viscaria copper mine, Sweden. CIM Bulletin, 90(1030), 82-89.

[32] Sheputis, A. (1966). Obobshcheniye odnoy teoremy Kramera. Litov Matematicheskiy Sbornik, 6(4), 640-641

[33] Gao, Z.-M., He, Y., \& Wu, M. (2019). Improved stability criteria for the neural networks with time-varying delay via new augmented Lyapunov-Krasovskii functional. Applied Mathematics and Computation, (349), 258-269. https://doi.org/10.1016/j.amc.2018.12.026

[34] Rastrigin, L., \& Madzharov, N. (1977). Vvedeniye v identifikatsiyu ob yektov upravleniya. Moskva, Rossiya: Energiya.

[35] Morkun, V., Morkun, N., \& Pikilnyak, A. (2017). Ultrasonic facilities complex for grinding and ore classification process control. 2017 IEEE 37th International Conference on Electronics and Nanotechnology (ELNANO), 409-413. https://doi.org/10.1109/elnano.2017.7939788

[36] Mikhlin, Y.V., \& Zhupiev, A.L. (1997). An application of the inch algebraization to the stability of non-linear normal vibration modes. International Journal of Non-Linear Mechanics, 32(2), 393-409. https://doi.org/10.1016/s0020-7462(96)00047-9

[37] Kovalev, A.M., Martynyuk, A.A., Boichuk, O.A., Mazko, A.G. Petryshyn, R.I., Slyusarchuk, V.Y., \& Slyn'ko, V.I. (2009). Novel qualitative methods of nonlinear mechanics and their application to the analysis of multifrequency oscillations, stability, and control problems. Nonlinear Dynamics and Systems Theory, 9(2), 117-145.

[38] Slyusarchuk, V.E. (1983). Exponential dichotomy for solutions of discrete systems. Ukrainian Mathematical Journal, 35(1), 98-103. https://doi.org/10.1007/bf01093176

[39] Aref'yev, B. (1969). Optimizatsiya inertsionnykh protsessov. Leningrad, Rossiya: Mashinostroyeniye.

[40] Gu, D-K., \& Zhang, D-W. (2020). Parametric control to secondorder linear time-varying systems based on dynamic compensator and multi-objective optimization. Applied Mathematics and Computation, (365), 124681.

[41] Zaghdoudi, M., \& Jammazi, C. (2017). On the partial rational stabilizability of nonlinear systems by optimal feedback control: Examples. IFAC-PapersOnLine, 50(1), 4051-4056. https://doi.org/10.1016/j.ifacol.2017.08.725

[42] Haber, R.E., del Toro, R. M., \& Gajate, A. (2010). Optimal fuzzy control system using the cross-entropy method. A case study of a drilling process. Information Sciences, 180(14), 2777-2792. https://doi.org/10.1016/j.ins.2010.03.030

[43] Beattie, N. (2012). Monitoring-while-drilling for open-pit mining in a hard rock environment. Master's thesis. Kingston, Canada: Queen's University.

[44] Galiev, S.Z., Galiev, D.A., Seitaev, E.N., \& Uteshov, E.T. (2019). Unified methodology for management of a geotechnological complex in open pit mining. Gornyi Zhurnal, 2019(12), 70-75. https://doi.org/10.17580/gzh.2019.12.15

[45] Chinayev, P. (1969). Samonastraivayushchiyesya sistemy. Kyiv, Ukraina: Naukova dumka.

[46] Ballesteros-Escamilla, M., Chairez, I., Boltyanski, V.G., \& Poznyak, A. (2018). Realization of robust optimal control by dynamic neural-programming. IFAC-PapersOnLine, 51(13), 468-473. https://doi.org/10.1016/j.ifacol.2018.07.322

[47] Martin, J. (2013). Application of pattern recognition techniques to monitoring-while-drilling on a rotary electric blast hole drill at an open-pit coal mine. Master's thesis. Kingston, Canada: Queen's University.

[48] Pan, X. (2012). Optimization of mineral processing plant through ROM ore size. AGH Journal of Mining and Geoengineering, 36(4), 123-132. 


\section{Адаптивне керування процесом буріння в умовах нестаціонарності на основі ідентифікації параметрів моделі об'скта}

В. Моркун, Н. Моркун, В. Тронь, Д. Паранюк, Т. Сулима

Мета. Метою роботи є дослідження і синтез адаптивного керування процесом буріння в умовах нестаціонарності на основі ідентифікації параметрів моделі об’єкта.

Методика. В умовах показників процесу буріння свердловин, що досить швидко змінюються, використана стратегія дворівневого адаптивного управління, яка полягає в одночасному дослідженні процесу буріння й керуванні даним процесом. При цьому в структуру системи керування додатково включено блок формування моделі на основі інформації про непрямі ознаки.

Результати. Розглянуто метод пошуку екстремуму стосовно об'єкта, динаміка якого описується лінійним диференціальним рівнянням першого порядку. Метод дозволяє по початковій ділянці перехідного процесу в об'єкті, викликаного зміною вхідного сигналу на заданий крок, визначити стале значення вихідного сигналу об’єкта.

Наукова новизна. Пропонований алгоритм перешкодозахищеної ідентифікації дозволяє оцінити величину коефіцієнта передачі об’єкта керування в умовах дії випадкових перешкод. Отримана інформація використовується для ефективного налаштування коефіцієнта посилення регулятора у замкнутій системі автоматичного керування технологічним процесом буріння.

Практична значимість. Запропоновані структура і алгоритм керування процесом буріння, що дозволять підвищити ефективність процесу буріння свердловин, забезпечивши оптимальну механічну швидкість буріння шляхом визначення відповідних значень частоти обертів і осьового навантаження породоруйнуючого інструменту.

Ключові слова: адаптивне управління, буріння, нестаціонарність, ідентифікація, модель

\section{Адаптивное управление процессом бурения в условиях нестационарности на основе идентификации параметров модели объекта}

В. Моркун, Н. Моркун, В. Тронь, Д. Паранюк, Т. Сулима

Цель. Целью работы является исследование и синтез адаптивного управления процессом бурения в условиях нестационарности на основе идентификации параметров модели объекта.

Методика. В условиях достаточно быстро изменяющихся показателей процесса бурения скважин использована стратегия двухуровневого адаптивного управления, которая заключается в одновременном исследовании процесса бурения и управлении данным процессом. При этом в структуру системы управления дополнительно включен блок формирования модели на основе информации о косвенных признаках.

Результаты. Рассмотрен метод поиска экстремума применительно к объекту, динамика которого описывается линейным дифференциальным уравнением первого порядка. Метод позволяет по начальному участку переходного процесса в объекте, вызванного изменением входного сигнала на заданный шаг, определить установившееся значение выходного сигнала объекта.

Научная новизна. Предлагаемый алгоритм помехозащищенной идентификации позволяет оценить величину коэффициента передачи объекта управления в условиях действия случайных помех. Полученная информация используется для эффективной подстройки коэффициента усиления регулятора в замкнутой системе автоматического управления технологическим процессом бурения.

Практическая значимость. Предлагаемая структура и алгоритм управления процессом бурения позволяют усилить его эффективность путем обеспечения необходимой скорости механического бурения, определения соответствующих скоростей вращения и осевых нагрузок на бурильный инструмент.

Ключевые слова: адаптивное управление, бурение, нестационарность, идентификация, модель

\section{Article info}

Received: 11 December 2018

Accepted: 17 February 2020

Available online: 5 March 2020 